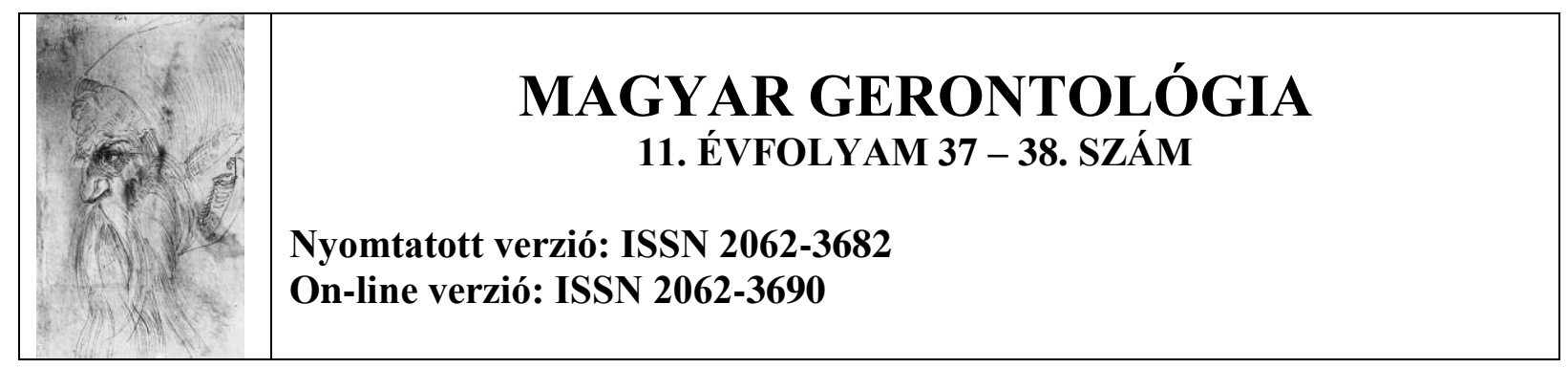

\title{
EVOLÚCIÓS ÉS TÁRSAS HATÁSOK SZEREPE A NAGYSZÜLŐI GONDOSKODÁS ALAKULÁSÁBAN
}

Dr. Csinády Adriána

Debreceeni Egyetem, Pszichológiai Intézet, Személyiség és Klinikai Pszichológiai Tanszék

\section{Dr. Csinády Adriána}

Levelezési cím: Pszichológiai Intézet, 4002 Debrecen, Pf. 400.

Telefon: (30) 883-8286

Fax: (52)512-900/23665

\section{Összefoglaló}

A nagyszülők szerepe nagyon meghatározó az életünkben mind szülöként, mind unokaként. Az a törődés és gondoskodás, amit ők nyújtanak érzelmileg meghatározó élmény, ami egyben kötődési mintául is szolgál. Már ősidők óta szerepe van a nagyszülöknek, elsősorban a nagymamáknak az unokák túlélésében. Feltehetően a postmenpauzális nőknek, a nagymamáknak köszönhető hogy az ember gyermekénél a hosszú fejlődés időszaka kialakulhatott, aminek rendkívüli a jelentősége az ember kognitív evolúciójában.

Azonban számos kérdés vetődik fel a nagyszülői segítségnyújtás tekintetében, melyekre mind evolúciós, mind szociális magyarázatokkal szolgálnak a kutatók. Ezen kutatások számba veszik mért jelenhetett meg a nagymamai szerep a humán evolúcióban, milyen faktorok befolyásolják a nagyszülői segítségnyújtást és azt, hogy a szülők, unokák miképp viszonyulnak majd ehhez.

Kulcsszavak: postmenopauzális nők, nagyszülő, nagymama hipotézis, evolúció, természetes szelekció 


\title{
THE ROLE OF VOLUTION AND SOCIAL EFFECTS IN GRANDPARENTAL CARE
}

\begin{abstract}
The role of grandparents is very important in our lives both as parents and as grandchildren. The care provided by them is an emotionally influential experience that also serves as an attachment pattern. The grandparents, especially the grandmothers, have had a role in the survival of grandchildren since ancient times. Presumably it was the postmenpausal women, the grandmothers, whom made it possible that human children began to have a long developmental period, which is of great importance in human cognitive evolution.

However, there are a number of questions about grandparental help, answered by researchers with both evolutionary and social explanations. These studies take into account how the grandmother's role appeared during human evolution, what factors influence grandparental help and how the parents and grandchildren will relate to it.
\end{abstract}

\section{Keywords: women after climax, grandparents, grandmother hipothesis, evolution, natural selection}

\section{Bevezetés}

A világ különböző tájain a gyermeknevelési szokásokban jelentős különbségek mutatkoznak. (Hrdy, 1999). A társadalmak eltérő értékrenddel viszonyulnak a különböző korcsoportokhoz, van ahol a fiatalságot, van ahol az idős kor megélését tekintik értéknek. Manapság a nyugati társadalmakra jellemző neontokrácia a gyereket emeli a figyelem középpontjába csak utána jönnek a szülők majd a sor végén vannak a társadalom és a család idős tagjai. Ezzel szemben a hagyományos agrártársadalmakban jellemző a gerontokrácia, amelyben a társadalmi hierarchia csúcsán az ősök vannak, őket követik az idősebbek, felnőttek, serdülők és végül a gyermekek. (Lancy, 2015; Lancy, 2017).

Annak ellenére, hogy a társadalom hozzáállása az idős illetve a fiatal generációk szerepeinek meghatározásában eltérő lehet, a idősödő generációk mindig feladatknak tekintették a fiatalabb utódok gondozását, táplálását, mely akár azok túlélését is elősegíthette. Annak ellenére, hogy manapság a nyugati világ az ifjúságot dicsőíti és komoly infrastrukturával (bölcsőde, óvoda, iskola, bébiszitter szolgálatok) biztosítja azok ellátását, a nagyszülői gondoskodás még mindig komoly értéket képvisel a társadalomban. A nagyszülöi gondoskodás ma is komoly segítséget jelent a családok életében, mégha nem is a gyermek túlélése a központi célja, de befolyásolhatja azok testi, lelki és szellemi fejlődését egyaránt. 
Fő kérdésünk az lehetne, hogy mi az oka annak, hogy a nagyszülői törődés kialakult az emberi evolúció során? Továbbá, azt is szeretnénk megtudni, hogy nagyszülők mért nem egyenlő arányban invesztálnak unokáikba?

\section{Nagymama hipotézis}

Az ember állatvilágból való kiemelkedésének számos oka lehet. Az emberi agy nagy mérete a csoportos életforma, illetve a hosszú gyermekkor mind segítették az ember kognitív evolúcióját (Bjorklund, Grotuss, Csinady, 2009). Tudjuk, hogy az emberi gyermeknek sokkal több pótszülői segítségre volt és van szüksége és ezt sokkal tovább veszi igénybe, mint bármely emberszabású rokona, ezen alloparentációban részt vevő gondozók közül az egyik legkiemelkedőbb jelentőségük a nagymamáknak van. Ennek a problémának a megoldására az emberi evolúcióban egy érdekes adaptáció alakult ki a post-menopauzális nők esetében, ugyanis ők évtizedekkel tovább éltek még az utolsó gyermekük születése után, ennek köszönhetően több élelmmel járultak hozzá a közösség asztalához, mint amennyit fogyasztottak. Számos kutató úgy vélekedik a nagymamák hosszú életkorának köszönhető, hogy az emberi gyermekkor ilyen hosszúra nyúlik illetve hogy az intelligencia jelentősen növekedett és nem pusztán a nagy méretú agy támaszt igényt a hosszú fejlődésre. (Hrdy, 1999)

Kezdjünk e téma tárgyalásába a legalapvetőbb evolúciós gondolattal a nagyszülöi tevékenység kialakulását illetően, a nagymama hipotáéissel, amit William Hamilton (1964) evolúciós biológus vetett fel először a '60-as években. Ez a hipotézis Hamilton inklúziv fitnessz fogalmára épül, mely szerint az egyének oly módon is növelhetik reproduktív sikerüket, ha nem saját szaporodásukba invesztálnak, hanem egy rokon túlélését segítik elő. A nők többnyire 20 évet élnek még az utolsó gyermekük születése után, mialatt támogathatják saját unokáik nevelését, hogy azzal elősegítsék túlélésüket. Tehát a postmenopauzális nők remek példát szolgáltatnak az inklúziv fitnessz fogalmára. Tovább erősíti a nagymama hipotézist, hogy az idős nők esélye a vetélésre rendkívül magas egy terhesség esetén és a szülési komplikációk is jelentösen megnőnek, ezzel együtt az alacsony súlyú és koraszülött utódok száma is nő, akik halálozási aránya magasabb és maguknak az idősebb anyáknak is nagyobb esélyük van arra, hogy szülés során elhalálozzanak (Kleine, Stein és Susser, 1981). Az idősebb nők jelentős munkát, figyelmet, időt fektethetnek a saját idősebb gyermekeik és unokáik felnevelésébe, ezzel azok túlélését elősegítik, amennyiben ezt az energiát új utódok kihordására, megszülésére és nevelére fordítanák, azzal veszélyetetnék a már meglévő gyermekeik és unokáik túlélését (Geary és Flinn, 2001). 
Az állatvilágban viszonylag kevés a bizonyíték a nagymama hipotézisre, hiszen a vadonban az idősebb állatok jobban ki vannak téve annak, hogy áldozatul essenek ragadozóknak vagy más erejük teljében lévő csoporttagoknak. A nagyszülői gondoskodás azonban nem egyedülálló emberi jelenség. Alkalmanként gondoskodó nagymamai viselkedést figyeltek meg több főemlősnél, például vadon élő csimpánzoknál és páviánoknál (Collins, Busse és Goodall, 1984), az elefántoknál (Lee, 1987), valamint a delfineknél (Pryor és Norris, 1991), és agyilkos bálnáknál (Brent és mtsai., 2015; Foster és mtsai., 2012). Néhány madárfajnál is jellemző volt a viselkedés, így például egy seychelle szigeteki énekes madár (Seychelles warbler) volt az első olyan madárfaj, melynél a nagymamai segítségnyújtást megfigyelték (Richardson, Burke és Komdeur, 2007).

Más fajokhoz képest azonban az emberi nagyszülőnek három egyedi jellemzője van ami megkülönböztet minket más fajoktól a nagyszülői gondoskodás tekintetében:

- a gondoskodó nagyszülők rendszeresen nyújtanak segítséget az unokáknak és nem alkalomszerüen, mint más fajoknál,

- gondoskodó nagypapai szerep kizárólag human jellegzetesség, és

- a nők meglehetősen hosszú posztmenopauzális élettartama is megkülönböztet minket a legtöbb olyan emlös fajtól ahol egyáltalán beszélhetünk a menopauza megjelenéséröl (Euler, 2011).

A nagymamai gondoskodás evolúciója feltehetően a menopauza és az emberi nőstények hosszú poszt-reprodukciós élettartama miatt alakulhatott ki (Coall és Hertwig, 2010). A nagymama hipotézis szerint az emberi nőstények korán befejezik saját reprodukciójukat más fajok nőstényeihez képest, mert több fitnesz-előnyt szerezhetnek ha a már megszületett utódaikba invesztálnak, mintha saját reprodciójukkal lennének elfoglalva (Hawkes, 2003; Hawkes és Blurton-Jones, 2005).

Szemléletes példát szolgáltat erre Jane Goodall leírása Flo nevü csipánzáról, aki jó anya volt és számos utódot hozott a világra és gondozott. Idős kora ellenére szülte meg Flint nevü utódját. Flint még nem volt teljesen elválasztva, amikor Flo megint várandós lett és életet adott Flame-nek. Röviddel ezután sajnos Flame és Flo is elpusztultak, Feltehetően Flo idős szervezetére terhesség és a szoptatás is rendkívüli stresszhatást gyakorolt. Ennek eredményeként sajnos Flint árva maradt, és egy hónapon belül ő is meghalt az anyja elvesztése után. Mindezek ellenére Flo estete nem lett evolúciós kudarc, hiszen már három felnőtt szaporodóképes utódja volt Flint és Flame születése előtt. De további reprodukciós sikere akkor lehetett volna, ha Flint után már nem szül több utódot. Sarah Hrdy prímológus szerint a nagymama hipotézist inkább a „Bölcs Anya Hipotézis” elnevezéssel kellene illetni, 
hiszen, aki „időben hagyja abba” a szaporodást, annál garantált, hogy lesz még ideje gondoskodni az utódról, hogy a reproduktív vállalkozás sikerrel záruljon.” (Hrdy, 1999)

Érdekes tény az evolúcióban, hogy a természtes szelekció az egyedfejlődés alacsonyabb szintjein fejti ki leginkább hatását. Így elmondhatjuk, hogy a fiatal utódok esetében a legerőteljesebb a hatása, hiszen ők akkor lehetnek csak evolúciós értelembegn sikeresek, ha elérik a serdülőkort és maguk is nemzőképessé válnak. Ellenben idősebb korban erre már nincs ilyen erőteljes szelekciós nyomás, ezért a már befejezett szaporodás után az egyén számára már nem bizosít védőfaktorokat a természet, így azok több betegségnek vannak kitéve (Grotuss Bjorklund és Csinady, 2007).

Érdekes ténnyel szolgál számunkra Schwarz és munkatársai (2016) vizsgálata, melyben egy immunszabályozó gén egy változatát vizsgálták, amelyet CD33-nak neveznek. Ez a gén az emberben azzal a céllal alakulhatott ki, hogy védelmet nyújtson az Alzheimer-kór időskori megjelenése ellen. Ha a csimpánzoknál létezne ilyen betegség, nyilvánvalóan hátrányos lenne éppúgy, mint az embereknél. Mivel azonban a csimpánzoknál nincs meghosszabbodott postreprodukciós élettartam, így ennél fajnál nem volt evolúciós nyomás az Alzheimer-kór pusztító hatásainak enyhítésére. Alapvetően a reprodukció beteljesülése után a természetes szelekció folyamatai enyhülnek és már nem segítik az egyén túlélését (Bjorklund és Pellegrini, 2001). A nagymama hipotézist, úgy tűnik tovább erősíti ennek ismerete.

\section{A hadzák világa}

A Hadza népcsoport tagjai modern kori vadászó gyüjtögetők Tanzániában. Olyan életformát tartanak fenn, amiröl úgy gondoljuk, hasonló az őseink több ezer éven át gyakorolt létformájára, ahol a nők gyüjtögettek a férfiak pedig vadászattal foglalkoztak. A Hadzáknál a nők jelentősen több kalóriamennyiséget tesznek a családi asztalra a gyüjtögetéssel, mint a férfiak a vadászattal (Hawkes és mtsai, 1997). Sőt a legkeményebben dolgozó gyüjtögetők a postmenopauzális nők.

A nagymamák azok, akik ehető gyökereket biztosítanak, több gyümölcsöt gyüjthetnek, mint amennyire szükségük van, és akik a mézet beszerzik, ami különösen értékes. A tizenévesek és a friss házasok naponta három órát gyüjtögetnek; a házas nők kisgyermekekkel átlagosan négy és fél órát (ők közben magukon hordjúk gyermeküket és közben szoptatnak is), míg a nagymamák hét órát is gyüjtögetéssel töltenek.

Nem is meglepő, hogy az unokák testtömege arányosan nő azzal, ahogy nagymamáik hozzájárulnak a családi éléskamrához. Sőt, a Hawkes és munkatársai (1997) által 
tanulmányozott Hadzáknál jellemző volt, hogy minden szoptató anyát egy posztmenopauzális segítő támogat, aki szinte mindig a nő anyja vagy anyósa.

Közismert az a gondolat mely szerint a nagyszülők már „nem nevelgetnek, hanem szeretgetnek"- az unokák és nagyszülők kapcsolata többnyire önzetlen, a nagyszülők nem a szigorú nevelő szerepet töltik be a gyerekek életében, hanem valóban minőségi időt tudnak eltölteni velük. Azonban nagyon eltérő lehet az, hogy egyes családok életében milyen mértékben vannak jelen a nagyszülők. Van ahol az unokák napi kapcsolatban vannak velük, más családokban csak a hétvégéken adódik lehetőség a találkozásra. Jelentős tényező lehet a nagyszülők egészségi állapota, mentális állapota is, milyen mértékben képesek részt venni unokáik életében.

Manapság a középosztálybelieknél a nagy kiterjedt családok még szükségszerübbek volnának, mint valaha, mivel az anyának és apának teljes munkaidőben kell dolgoznia, rendkívüli segítség, ha a nagyszülők legalább a gyermeknevelés egy részét magukra vállalják. Tulajdonképpen olyan ez, mint egy modern Hadza forgatókönyv, a high-tech világban, mely már nem pusztán a gyermek fizikai túlélését segíti, de előnyöket nyújt az utódnak a társadalmi siker szempontjából is.

\section{Melyik nagyszülő invesztál legtöbbet?}

Miért különböznek a nagyszülők egymástól a tekintetben, hogy ki mennyit invesztál az unokákba? Az egyenlőten nagyszülői befektetési mintázat hátterét számos evolúciós elmélettel próbálták alátámasztani, melyek közül Hamilton (1964) rokon szelekciós elmélete és Trivers (1972) szülői ráfordítás elmélete a legismertebb. Ezek szerint e jelenség fö okai lehetbek a nem specifikus reproduktív stratégiák, az apasági bizonytalanság illetve, hogy mennyire kedvelünk egy unokát. A rokon szelekciós elmélet szerint egy egyén fokozhatja evolúciós rátermettségét azáltal, hogy támogatja közeli hozzátartozóit azok reproduktív sikerében ezzel növelve saját reproduktív sikerét is. Az ember saját gyermekével átlagosan $50 \%$ genetikai azonosságot mutat és $25 \%$-ot az unokájával. Emellett a reproduktív érték meghatározó abban, hogy ki kap több támogatást a rokonok részéről. A fiatalok reproduktív értéke magas, míg az idősebb személyeké alacsonyabb így várhatóan a nagyszülők az utódaik gyermekeibe fognak invesztálni (Hughes, 1988). Tehát a rokon szelekciós elmélet szerint, az embereknek előnyben kell részesíteniük gyermekeiket és unokáikat, hiszen ott nagyobb mértékú a génazonosság, míg a háttérbe szorulnaka a távolabbi rokonok, az idősebb rokonok és a barátok. 
Az emberekre jellemző a szex specifikus reproduktív stratégiák használata. Ezek abból fakad, hogy a nők számáraminden egyes utód költségesebb, hiszen kilenc hónap terhességet igényel majd pedig több év gondozást és táplálást (Trivers, 1972). Anyai a befektetés kötelező jellegü, míg az apai befektetés választható. Ezt mutatja például az a tény, hogy az anya elvesztése sokkal nagyobb károkat okoz az utód számára, mint egy apa vagy más gondozó elvesztése (Sear és Mace, 2008). Tehát az evolúciós múltban az anyák az inklúziv fitneszüket úgy maximalizálhatták legjobban, ha gondoskodtak utódiakról (Euler, 2011). Ennek megfelelően alakult számos pszichológiai mechanizmusunk, mely a nőket a godoskodásra alaklmassá tette, mint például az empátiás készség magas színvonala, és a gyerekek iránti vonzalom (Rotkirch és Janhunen, 2010).

\section{Hogyan illeszthető az evolúciós szemlélet a mai világ nagyszülői tevékenységére?}

Manapság a genetikai tesztek világában könnyü fényt deríteni arra, hogy kié a gyerek, de korábban csak a nők lehettek biztosak abban, hogy gyermekük, akit a világra hoznak száz százalékban az ő genetikai utódjuk. Ezzel szemben a férfiak az evolúció során sosem lehettek teljesen biztosak abban, hogy utódjuk valóban az ő saját genetikájukat hordozza-e. A nagyszülőkre lefordítva ezt a gondolatot, tulajdonképpen azt mondhatjuk, hogy csak az anyai nagymama lehet száz százalékig biztos abban, hogy lánya gyermeke az ő genetikai rokona is egyben. Az anyai nagypapáknak és az apai nagymamáknak már van egy bizonytalan rokoni kapcsolatuk, az unokát illetően, míg az apai nagypapának kettő. Magától értetődően ez lesz a sorrend az utódba való befektetések mértékét illetően is (Euler és Weitzel, 1996).

Ugyanakkor ezzel a gondolatsorral nem bizonyítható az a tény, mely szerint az anyai nagypapák többet segédkeznek az unokák mellett, mint az apai nagymamák, pedig a nagyszülői genetikai bizonyosság azonos mértékü. Gyakran úgy magyarázzák ezt a jelenséget, hogy az anyai nagypapa a felesége által növeli meg befektetéseit a lánya gyermekébe, hiszen a feleség, aki tökéletesen biztosan a saját unokáját támogatja, invesztál egyben a legtöbbet, ebbe bevonva férjét az anyai nagypapát is (McBurney és mtsai, 2002).

De nemcsak az evolúciós tényezőknek lehet szerepe abban, hogy ki és mennyit segít az unokák körül, hanem olyan társas faktoroknak is, mint például a földrajzi közelség vagy az érzelmi kötődés, a szülői és nagyszülői generációk családi állapota, mind befolyásolhatják a nagyszülői befektetés mértékét és mintázatát. Egyértelmü magyarázattal szolgálhatna ezekre a kérdésekre a nagyszülök közötti életkori különbség. Ez alapján feltételezhetjük, hogy többnyire az anyai nagymama a legfiatalabb, és így valószínűleg még életben van, míg az apai 
a nagyapa általában a legidősebb, és valószínüleg ő van a legrosszabb egészségi állapotban vagy már esetleg elhunyt (Coall és Hertwig, 2010).

Még érdekesebb, hogy a nagyszülöi befektetés az alábbi mintázatot követi: az anyai nagymama az, aki a legtöbbet invesztál unokáiba, öt az anyai nagypapa követi és az apai nagymama, míg az apai nagypapa van többnyire a sor végén a nagyszülői segítségnyújtásban. Ez a sorrend többnyire általános azokban az országokban, ahol nincs kifejezett preferencia a matrilineáris vagy patrilinealis családi kapcsolatokra (Coall és Hertwig, 2011).

Függetlenül attól, hogy mi okozza a hosszú életet a reproduktív szakasz lezárulása után a nőknél, lenyügöző empirikus bizonyíték van arra, hogy a nagyszülők és a nagymamák ténylegesen segítették sok esetben a gyermekek túlélését (Sear és Mace, 2008), és manapság is jellemző ez a tradícionális társadalmakban (Hawkes, O'Connell, és Blurton Jones, 1997). Mint láttuk, a ma élő tradícionális vadászó-gyüjtögető társadalmakban például a nagymamák elősegítik a gyermekek táplálkozását, és ezáltal növelik az unokáik túlélési esélyeit (Hawkes mtsai, 1997). A mai nyugati világban ugyan alacsony a csecsemő és gyermekhalandóság és a nagyszülők ritkán kellenek a gyermekek túléléséhez. Ennek ellenére a nagyszülői jelenlét még mindig befolyással van a gyermekeik reproduktiv döntéseit és unokáik jólétét illetően. Az előző szerint, a nagyszülök bevonása fontosnak tünik a jólét szempontjából különösen egy családi krízishelyzet esetén (pl szülő halála vagy válás) (Sear és Coall, 2011). Bizonyíték van arra is, hogy a modern a nagyszülők pozitív hatással lehetnek a szülői gyermekvállalási döntésekre (Tanskanen és Rotkirch, 2014), valamint jelenlétük pozitív hatással van unokáik jólétére és fejlődésére (Tanskanen és Danielsbacka, 2012).

A szociológiai tanulmányokban a nagyszülöket nem mindig különböztetik meg nemük és családi hovatartozásuk szerint, ennek ellenére a kutatók többnyire elismerik a a biológiai változók jelentőségét, így a nem és a származás kiemelten fontosak (Chan és Elder, 2000). A nagymamák és a nagyapák unokákba fektetett idő pénz, energia különbségeit próbálja magyarázni a rokoni kapcsolattartók elmélete. Az elmélet feltételezi, hogy a szociális normák és elvárások arra sarkallják a nőket, hogy aktívabban kivegyék részüket a családi kapcsolatok ápolásából illetve a családtagok ellátásából. A nők biológiai természetüknél fogva sokkal gondoskodóbbak, mint a férfiak, és a társadalom számít e gondoskodásra, következésképp a nőket úgy szocializálják, hogy kötelességüknek tekintsék a családon belüli kapcsolatok ápolását. Így a nagymamák, különösen az anyai nagymamák, sokkal többet fognak unokáik gondozásába invesztálni és a kapcsolatuk és kötődésük az unokákkal különösen szorossá fonódik, míg a nagypapák és unokák viszonya nem alakul ilyen bensőségessé, hiszen nincsenek erre vonatkozóan meghatározó társadalmi elvárások (Bracke, Christiaens és 
Wauterickx, 2008). Összehasonlítva a szociológiai és az evolúciós gondolkodást a nagyszülői befektetések eltérő mértékéröl, azt mondhatjuk, hogy mindkét elmélet egyetért abban, hogy a nők szerepe a gyermekeik ellátásában kötelező feladat, a fő különbség a két gondolatmenetben ott található, hogy míg az evolúciós elmélet biológiailag meghatározottnak tartja ezt a feladatot, a szociológiai gondolkodás szerint ez alapveően egy tanult viselkedésforma, amit a neveltetésünk által kényszrítenek ránk.

A szülők, nagyszülők és unokák közötti érzelmi kapcsolatok jelentőségét kiemelik a szociológiai kutatások, ezekben a szülők, a közvetítők szerepét töltik be, így jelentős szerepet kap benne a szülői-nagyszülői viszony minősége. A legtöbb evolúciós kutatással ellentétben itt figyelembe veszik, hogy a nagyszülők segítségnyújtását a gyermekeik, az unokák szülei, nem mindig fogadják el (Barnett és mtsai, 2010).

A nagyszülői befektetés függ attól a történekmi helytől és időtől amilyen korban az emberek élnek és a kulturális hatásoktól (Kemp, 2007). A családi kapcsolatok mélyen összefonódnak és a családtagok minden egyes kapcsolatát más családládtagokkal befolyásolja a többi családi kapcsolatuk (Cox és Paley, 1997), valamint az egyes életkorok és életszakaszok is befolyásolják a családtagok a közti kapcsolatok alakulását (Elder, 1994). Az, hogy ki mennyi segítséget fog nyújtani az unokák számára függ az arra vontakozó szükségletektől illetve a segítségnyújtó nagyszülő lehetőségeitől is.

\section{A kontextus jelentősége a nagyszülooi segítségnyújtásban}

Más fajokkal ellentétben az emberi családi rendszerek rendkívül alkalmazkodóak. Rendkívül változatosak, mind a megélhetési, a házassági és a letelepedési szokások (Sear, 2015). Ugyanakkor az alapvető stratégiai döntési minták - mint a rokonszelekció, az apaság kérdése, szex specifikus reproduktív stratégiák - változatlanok. A kérdés, amely összekapcsolja az evolúciós kutatást a szociológiai jellegű családkutatásokkal, az a kontextus fontossága és annak hatása.

A kontextus például meghatározó atekintetben, hogy a nagyszülők közreműködése az unokák ellátásában valóban pozitiv hatással jár-e. A nagyszülők segítsége, sajnos nem feltétlenül növeli a gyermek jólétét minden helyzetben. Azok a viselkedési minták, melyek az ősi vagy mai vadászó-gyüjtögető társadalmakban segítették a gyermekek életben tartását, ma már nem kívánt eredményeket hozhatnak (Hawkes és mtsai, 1997). Például, a modern jóléti társadalmakban az unokák jó falatokkal való kényeztetése a gyermekek elhízásához vezethet (Tanskanen, 2013). 
Olyan környezetben, ahol az eröforrások nem megfelelöek, nagyszülök - különösen az idősebbek - lehet, hogy nem nyújtanak segítséget, hanem fiatalok versenytársaivá válnak az erőforrásokért (Strassmann, 2011; Strassmann és Garrard, 2011). A kulturális kontextust tehát a nagyszülői szerepeknél nem lehet figyelmen kívül hagyni.

\section{Irodalom}

Barnett, M. A., Scaramella, L. V., Neppl, T. K., Ontai, L., \& Conger, R. D. (2010). Intergenerational relationship quality, gender, and grandparent involvement. Family Relations, 59, 28-44.

Bjorklund, D. F., Grotuss, J., és Csinady, A. (2009). Maternal effects, social cognitive development, and the evolution of human intelligence. In D. Maestripieri és J. Mateo (Eds.), Maternal effects in mammals, (pp. 292-321). Chicago: Chicago University Press.

Bjorklund, D. F., és Pellegrini, A. D. (2002). The origins of human nature: Evolutionary developmental psychology. Washington, DC: American Psychological Association.

Bracke, P., Christiaens, W., \& Wauterickx, N. (2008). The pivotal role of women in informal care. Journal of Family Issues, 29, 1348-1378.

Brent, L. J. N., Franks, D. W., Foster, E. A., Balcomb, K. C., Cant, M. A., és Croft, D. P. (2015). Ecological knowledge, leadership, and the evolution of menopause in killer whales, Current Biology, 25, 746-750.

Chan, C. G. \& Elder, G. H. Jr. (2000). Martilineal advantage in grandchildgrandparent relations. The Gerontologist, 40, 179-190.

Coall, D.A., és Hertwig, R. (2010). Grandparental investment: Past, present, and future. Behavioral and Brain Sciences, 33, 1-59.

Collins, D. A., Busse, C. D., és Goodall, J. (1984). Infanticide in two populations of savanna baboons. In Hausfater, G. és Hrdy, S.B. (eds.) Infanticide: Comparative and Evolutionary Perspectives. Hawthorne: Aldine, pp 193-215.

Cox, M. J. \& Paley, B. (1997). Families as systems. Annual Review of Psychology, 48, 243 267.

Elder, G.H. (1994). Time, human aging and social change. Perspectives on the life course. Social Psychology Quarterly, 57, 4-15.

Euler, H. A. (2011). Grandparents and extended kin. In Salmon, C. A., és Shackelford, T. K. (eds.), The Oxford Handbook of Evolutionary Family Psychology. New York: Oxford University Press, pp 181-210. 
Foster, E. A., Franks, D. W., Mazzi, S., Darden, S. K., Balcomb, K. C., Ford, J. K. B., és Croft, D. P. (2012). Adaptive prolonged postreproductive life span in killer whales, Science, 337, 1313.

Euler, H. A., and Weitzel, B. (1996). Discriminative grandparental solicitude as reproductive strategy. Human Nature, 7, 39-59.

Geary, D. C. és Flinn, M.V. (2001). Evolution of human parental behavior and the human family. Parenting: Science and Practice, 1, 5-61.

Grotuss, J., Bjorklund, D. F., Csinady, A. (2007). Evolutionary developmental psychology: Developing human nature. Acta Psycholigica Sinica. Vol. 39 No. 3, 439 - 453.

Hamilton, W. D. (1964). The genetical evolution of social behaviour (I and II). Journal of Theoretical Biology, 7, 1-52.

Hawkes, K. (2003). Grandmothers and the evolution of human longevity. American Journal Human Biology, 15, 380-400.

Hawkes, K. és Blurton Jones, N. G. (2005). Human age structures, paleodemography, and the grandmother hypothesis. In Voland, E.,Chasiotis, A., és Schiefenhövel, W. (eds.) Grandmotherhood: The Evolutionary Significance of the Second Half of Female Life. New Jersey: Rutgers University Press.

Hawkes, K., O'Connell, J. F., és Blurton Jones, N. G. (1997). Hadza women's time allocation, offspring provisioning, and the evolution of postmenopausal lifespans. Current Anthropology, 38, 551-578.

Hrdy, S.B. (1999). Mother Nature: Maternal Instincts and How They Shape The Human Species Ballantine Books, New York, NY.

Hrdy, S. B. (2009). Mothers and Others. The Evolutionary Origins of Mutual understanding. Cambridge, MA: The Belknap Press of Harvard University Press.

Hughes, A. L. (1988). Evolution and Human Kinship. New York: Oxford University Press. Hughes, M. E., Waite, L. J., LaPierre, T. A., és Luo, Y. (2007). All in the family: The impact of caring for grandchildren on grandparents' health. The Journals of Gerontology Series B: Psychological Sciences and Social Sciences, 62, S108-S119.

Kemp, C. L. (2007). Grandparent-grandchild ties. Reflections on continuity and change across three generations. Journal of Family Issues, 28, 855-881.

Lahdenperä, M., Lummaa, V., Helle, S., Tremblay, M., és Russell, A.F. (2004). Fitness benefits of prolonged post-reproductive lifespan in women. Nature, 428, 178-181. 
Lancy, D. (2015). The Anthropology of Childhood: Cherubs, Chattel, Changelings.

Cambridge University Press.

Lancy, D. (2017). Raising Children: Surprising Insights From Other Cultures. Cambridge University Press.

Lee, P. C. (1987). Allomothering among African elephants. Animal Behaviour, 35, 278-291.

McBurney, D. H., Simon, J., Gaulin, S. J. C., and Geliebter, A. (2002). Matrilateral biases in the investment of aunts and uncles: Replication in a population presumed to have high paternity certainty. Human Nature, 13, 391-402.

Pryor, K., és Norris, K. S. (1991). Introduction. In K. Pryor és K. S. Norris (Eds.), Dolphin societies: Discoveries and puzzles (pp. 1-3). Berkeley, CA: University of California Press.

Richardson, D.S., Burke, T., és Komdeur, J. (2007). Grandparent helpers: the adaptive significance of older, postdominant helpers in the Seychelles warbler. Evolution, 61, 2790-2800.

Rotkirch, A. és Janhunen, K. (2010). Maternal guilt. Evolutionary Psychology, 8, 90-106.

Sear, R. (2015). Beyond the nuclear family: An evolutionary perspective on parenting. Current Opinion in Psychology, 7, 98-103.

Sear, R., és Coall, D. (2011). How much does family matter? Cooperative breeding and the demographic transition. Population and Development Review, 37, 81-112.

Sear, R. és Mace, R. (2008). Who keeps children alive? A review of the effects of kin on child survival. Evolution and Human Behavior, 29, 1-18.

Schwarz, F., et al. Human-specific derived alleles of CD33 and other genes protect against postreproductive cognitive decline. Proceedings of the National Academy of Sciences 113, 74-79 (2016).

Tanskanen, A.O. (2013). The association between grandmaternal investment and early years overweight in the UK. Evolutionary Psychology, 11, 417-425.

Tanskanen, A. O., és Danielsbacka, M. (2012). Beneficial effects of grandparental involvement vary by lineage in the UK. Personality and Individual Differences, 53.

Tanskanen, A. O., és Rotkirch, A. (2014). The impact of grandparental investment on mothers' fertility intentions in four European countries. Demographic Research, 30, $1-26$.

Trivers, R.L. (1972). Parental investment and sexual selection. In Campbell, B. (ed.) Sexual Selection and the Descent of Man. Chicago, IL: Aldine, pp 52-97. 